\title{
LIST OF MAPS AND TABLES
}

\author{
Maps \\ 1 French North Africa \\ page xviii \\ 2 Afrique Occidentale Française (French West Africa, AOF) xix \\ 3 Afrique Equatoriale Française (French Equatorial Africa, AEF), \\ Madagascar, Réunion and Mauritius \\ $\mathrm{xx}$ \\ 4 French Indochina \\ xxi \\ 5 Syria and Lebanon \\ xxii
}

\section{Tables}

2.1 Registered European population in AEF, 1923.

3.1 French Indochina population figures, $1930 \quad 96$

3.2 French commerce and the colonies, 1928-32 102

3.3 Federal budget of Afrique Occidentale Française, 1928-33 107

3.4 Principal holders of French capital in Lebanon 115

9.1 Distribution of North African immigrants in France, March $1937 \quad 280$

10.1 Tirailleur Sénégalais recruitment for overseas service, $1923 \quad 329$

[ vii ] 